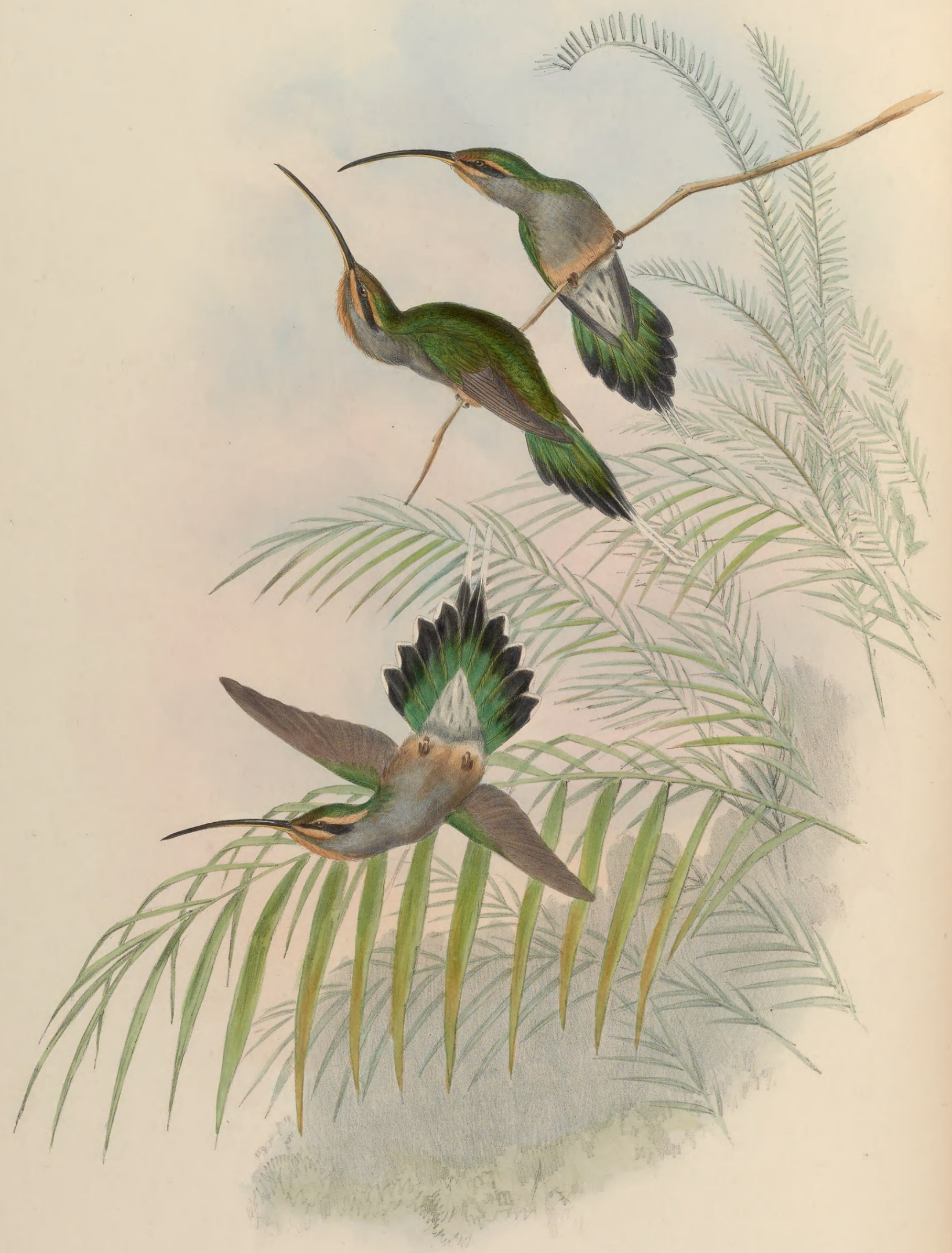

PHATFTHORIS GUY. 


\title{
PHAËTHORNIS GUY.
}

\author{
Guy's Hermit.
}

Trochilus Guy, Less. Les Troch., p. 119. pl. 44.

Phatornis Guy, Gray and Mitch. Gen. of Birds, vol. i. p. 104, Phatornis, sp. 6.

Phaёtornis Guy, Bonap. Consp. Gen. Av., p. 67, Phaëtornis, sp. 6.

Trochilus apicalis, Licht. in Mus. Berlin.-Tsch. Consp. Av., No. 199.-Ib. Faun. Peruana, p. 243.

Phatornis apicalis, Gray and Mitch. Gen. of Birds, vol. i. p. 104, Phatornis, sp. 17.

Phaëtornis apicalis, Bonap. Consp. Gen. Av., p. 68, Phaëtornis, sp. 17.

Trochilus Emilia, Bourc. Ann. de la Soc. d'Agr. Hist. Nat. etc. de Lyon, 1846, p. 317 ?

A Lengthened, but well-proportioned form, with wings and tail in every way in unison, renders this species of Phaëthornis one of the most elegant members of the genus yet discovered. At the same time, the changes of plumage, to which it appears to be subjected, are both numerous and perplexing; some specimens having the head much browner than others, the stripes down the throat more rufous, and the sides of the throat more extensively glossed with green: considerable difference occurs also in the form and colouring of the tail, some having the apical half of the lateral feathers nearly uniform black, and of a somewhat short and rounded form, with the prolonged portion of the central feathers very narrow; while in others, the lateral feathers are margined with white, and have the prolonged portion of the central tailfeathers broader and longer.

M. Bourcier has characterized a bird, the description of which closely accords with that of the specimens with the black tail, under the name of $T$. Emilice; but I possess numerous examples, intermediate in every respect between the states above described; and I am, therefore, inclined to think that his bird is only one of the states of the present species: still his view may be the correct one, and a further acquaintance with the subject may convince me that such is the case; but at present it appears to me that his $T$. Emilice is identical with $P$. Guy.

In the present state of uncertainty I am unable to say if any sexual differences of colour really exist, and it is, therefore, a subject to which I would particularly direct the attention of those who, residing in the country, may have opportunities for determining this point by actual dissection.

The habitat of $P$. Guy is Cayenne, La Trinité, Venezuela, and Santa Fé de Bogota, over which countries it is very generally dispersed.

Upper surface and wing-coverts glossy green; the feathers of the head inclining to brown, and narrowly edged with deep dull rufous; wings purple brown; upper tail-coverts glaucous green, with a crescent of black, and another of white at the tip; lores and ear-coverts blackish brown; a stripe above and behind the eye, another from the gape, and a third down the centre of the throat, deep buff; under surface ashy grey, glossed with green on the flanks, and passing into buff on the vent; tail-feathers glaucous green at the base, and black for the remainder of their length, the central ones largely tipped, and the lateral ones fringed on the outer portion of their tips with white; under tail-coverts greyish white, with darker centres; upper mandible and tip of the lower mandible black; basal two-thirds of the lower mandible fleshy red; feet brown.

The figures are of the natural size. 


\section{$2 \mathrm{BHL}$ Biodiversity Heritage Library}

Gould, John. 1851. "Phaëthornis guy, Guy's Hermit. [PI. 26]." A monograph of the Trochilidae, or family of humming-birds 1, https://doi.org/10.5962/p.316834.

View This Item Online: https://www.biodiversitylibrary.org/item/108333

DOI: https://doi.org/10.5962/p.316834

Permalink: https://www.biodiversitylibrary.org/partpdf/316834

\section{Holding Institution}

Smithsonian Libraries

\section{Sponsored by}

Smithsonian Institution Libraries

\section{Copyright \& Reuse}

Copyright Status: NOT_IN_COPYRIGHT

This document was created from content at the Biodiversity Heritage Library, the world's largest open access digital library for biodiversity literature and archives. Visit BHL at https://www.biodiversitylibrary.org. 